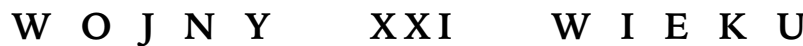

PIOTR OLEKSY, MARTA STUDENNA-SKRUKWA

Adam Mickiewicz University, Poznań

\section{REGIONAL IDENTITY, SEPARATISM AND WAR IN EASTERN EUROPE: DONBASS AND PRIDNESTROVIE}

Regional distinctiveness of the Donetsk Coal Basin and the Left Bank of the Dniester is often cited in order to account for the separatist movements on those territories. The article will therefore attempt to examine the relationship ensuing between regional identity, separatism and armed conflict in the aforesaid regions.

Here, regional identity is construed as a particular type of collective identity which, following Jan Assmann, is perceived as a "self-image that a body politic constructs, with which its members identify themselves" (Assmann 1992, p. 132; Straub 2006, p. 1133). In this approach, collective identity hinges upon self-identification of individuals and exists insofar as individuals subscribe to certain expectations, experience, and values they consider shared (Straub 2006, p. 1133). Regional identity is thus a "self-image" forged by a community which holds that its existence owes to inhabiting one territory. In this case, the expectations, experiences and communal values do not derive from ethnic kinship, religion or historical state community, but from joint historical experience and a sense of shared mentality and worldview. Melanie Tatur emphasizes that nowadays a "region" is "conceived as socio-cultural space constituted by cultural norms, personal networks, and 'regional identity"” (Tatur 2004, p. 35).

Adres do korespondencji: p.oleksy@amu.edu.pl, ORCID 0000-0002-7149-7945; stud nia@amu.edu.pl, ORCID 0000-0002-6197-543X 
The existence of such an identity might therefore be construed as a pre-condition thanks to which given space can be perceived as a full-fledged region. Moreover the process of "making regions" should be considered as "the construction of regional networks and the communicative creation of regional identity" (Tatur 2004, p. 35).

In both cases, separatism led to the war, which has later had fundamental significance for the political, social and cultural shape of the new socio-political entities-so called quasi-state or separatist republics. Both conflicts also bear the distinctive characteristics of "new wars" (also called postmodern wars or post-Clausewitzian wars-see Kaldor 2013; Reginia-Zacharski 2014, p. 279), which are fought in the name of identity, whereas economic and political goals often remain their actual but hidden agenda. The aim is to ensure particular groups-both local and transnational-access to the state power. Identity politics is constructed through war. Thus political mobilisation focusing on identity is the aim of war rather than an instrument of war, as was the case with "old wars" (Kaldor 2013).

Both wars were taking place on within one state, but with the participation of external forces. Those wars were mixtures of different forms of organised violence: revolt, strike, riots, civil war, intervention and banditry appeared with varying intensity. Also, a combination of actors were involved: regular armed forces (divided into different components such as army, national guard etc.), other armed state structures (police, special services), volunteer troops, criminal gangs, foreign volunteers motivated by ideology or by profit, and, last but not least, the external forces (Malendowski 2003, p. 28), which in both conflicts are represented by Russia. In Pridnestrovie, Russia exploits the nominal role of a stabilization force to pursue its own political and strategic interests, while in Donbass it officially denies the presence of its forces there, although it is actually the aggressor.

Violence against civilian population and violations of the law and customs of war, which are typical of the "new wars" (Kaldor 2013; Malendowski 2013, p. 33), have occurred in both cases, though with much more intensity in Donbass (Kuzio 2017, pp. 290-313). At the same time, the wars in Pridnestrovie and Donbass still display certain major traits of the "old" (Clausewitzian) wars: relatively large use of heavy weapons (artillery, tanks) and a decisive battle, which to a large extent became the founding myth of new identities.

After the conflict in Donbass broke out in spring 2014, the concept of hybrid war became popular both in journalism as well as in analyt- 
ical and scientific discourse. It is defined as a combination of the conventional warfare between two countries with the elements of civil war and terrorism, but it also involves a substantial and multi-faceted psychological-disinformative dimension. The lattes is a means to seize the opponent's territory with political means, by winning the "hearts and minds" of the population (Banasik 2015). However, the aim of the analysis conducted here is not to determine the extent to which the discussed conflicts fall under this definition, as the hybridity of the war is treated here as a feature of the "new type" of conflicts. The principal research question concerns the dependence between regional identity of the inhabitants of the areas affected by the conflict and their involvement in the conflict as well as the attitude to the territorial solutions that the conflict prompts.

It is presumed that the similarities between the quasi-state of Pridnestrovian Moldovan Republic and the "hybrid republics" of Donetsk and Luhansk are rooted in their pro-Russian political and cultural leanings, which are further boosted by the fact that they take ample advantage of Russian support. At the same time, it has to be stressed that the PMR and the "Donbass republics" were established at utterly different points in history. The Pridnestrovian movement was a response to Moldovan bid for separation from the Soviet Union, whereas Donbass separatism was a blatant violation of territorial integrity of an independent state. Separatist tendencies in Pridnestrovie grew out on its native soil: it all started with the local elite which had developed in the previous decades, and only then did it receive support from Russia. The emergence of the PMR was not accompanied by mass migrations, while the relations with Moldova saw gradual, relative normalization. In contrast, Donbass separatism was imposed by force by the hitherto marginal milieu of adherents of "Russkiy Mir." The proclamation of the DPR and LPR triggered a gigantic migration, chiefly to the territories controlled by Kyiv. The very moment when Russia became involved in the conflict can hardly be distinguished from the onset of the unrest.

In the case of Pridnestrovie we are dealing with the realities of a quasi-state, which have persisted for the last 27 years after secessionist war, whereas Donbass has been a region of Ukraine. Pridnestrovie offers an opportunity to study "nation-building" policies and the social responses to which they gave rise, while in Donbass this aspect surfaced only when the separatist republics had been proclaimed in 2014. Bearing in mind both the similarities and the differences, the authors will conduct a historical-comparative analysis. 


\section{THE EMERGENCE OF REGIONAL DISTINCTIVENESS \\ IN DONBASS AND PRIDNESTROVIE IN A HISTORICAL PERSPECTIVE}

In terms of social and cultural factors, Donbass and Pridnestrovie share a fair number of similarities. Both are Russian-speaking industrial regions while the simultaneous myth of multiculturalism proves a robust one. These traits owe to the modernization and industrialization which the regions underwent in the $19^{\text {th }}$ and $20^{\text {th }}$ century. Donbass and the left bank of the Dniester became territory of the Russian Empire in the $18^{\text {th }}$ century. The latter half of the $18^{\text {th }}$ century, and the $19^{\text {th }}$ century in particular saw the emergence and consolidation of Russian cultural dominance, as well as organized, multi-ethnic settlement. Nevertheless, the Left Bank of Dniester remained an agricultural land, meanwhile industrial mining of coal began to intensify in Donbass, leading to entailed demand for workforce, which was supplied by the Ukrainian and central Russian governorates. That "dominant Ukrainian-Russian coalition" replaced the $18^{\text {th }}$-century ethnic mosaic, although multi-ethnicity remained one of the major myths which reinforced regional identity (Kononov 2000, pp. 108-134; 2006, p. 17).

In the Soviet period, although Donbass became a part of the Ukrainian Soviet Socialist Republic, Russian language continued to predominate. The $19^{\text {th }}$ century witnessed assimilation into the Russian-speaking environment, since only Russian enjoyed the status of the language of high culture. Most technological specialists sent there in the first half of the $20^{\text {th }}$ century came from Russia. They considered themselves exempt from the Soviet project of Ukrainian nation-building, especially that to a substantial extent the industrial sector was outside its scope (Martyn 2013, pp. 117-169). The inflow of Russians enhanced the sense of Ukrainian-Russian ethnic community who thus became integrated both as inhabitants of the Ukrainian republic of the Union and sharers in the Russian cultural-linguistic sphere. The significance of the coal-mining industry, as well as miners' ethos engendered an enduring sense of pride and uniqueness in the region.

The territory the left bank of the Dniester was initially integrated by the Soviet power into the Ukrainian SSR, but in 1924 the Moldovan Autonomous Soviet Socialist Republic (MASSR) was created. This entity came into existence in order to propagate Soviet communism in Romania and the Balkans, as well as to lay groundwork for future cultural, institutional and human assets of the Soviet Moldova (Galushchenko 2001). After World War II, the left bank territories were incorporated into the newly-created 
Moldovan Soviet Socialist Republic. In the 1950s and the 1960s, large production plants specializing in heavy and light industry were built in the region. The industrial left bank differed palpably from the rest of the Moldovan SSR, which retained its agricultural character (Büsher 2010, pp. 242-243; Troebst 2002/2003, p. 7). The differences between the two banks of the Dniester were evident in ethnic structure: on the left bank, merely $35 \%$ of the inhabitants were ethnic Moldovans, while in whole republic they accounted for $65 \%$ of the population. Also, the need to supply qualified workforce for the new factories meant a mass influx of Russians and Ukrainians into the region. Already in the 1970s the economic elite on the left bank was simultaneously the political elite of the region. The process definitely fostered development of strong, informal, clan-like relations among members of the group (Troebst 2002/2003, p. 23). The qualified professionals and officers originating from across the USSR saw themselves as an "imperial" group in provincial Moldova. They perceived Soviet Union as their native state, while Soviet identity was particularly strong in that group. Close and evident ties with Moscow only served to reinforce it.

\section{PRIDNESTROVIAN STATE-BUILDING MOVEMENT AND THE ORIGINS OF WAR}

Two factors were instrumental in the emergence of Pridnestrovian state-building movement: the potency of Soviet identity among the inhabitants of the region and the determination of the regional elite to retain the privileges it had formerly enjoyed in the USSR. The movement represented a response to the national awakening of Moldovans and the policy of MSSR authorities, who pushed for cultural Romanization of the republic, strove to achieve as extensive an autonomy as possible within the USSR, and subsequently make a bid for independence or integration with Romania. In 1989, the Supreme Council of the MSSR enacted laws which granted Romanian the status of the sole official language in the republic and adopted Romanian state symbols as the country's own. Actual control of the Supreme Council was seized by the Popular Front of Moldova (PFM), a mass social-political organization of Moldovan national movement. The course adopted by the authorities of the MSSR was a real threat to the social position of the left-bank elite, composed chiefly of directors of the largest industrial plants, who often held high offices in the regional administration. The symbolic policy of Chişinău, based on Romanian national identity, stood in contradiction to the Soviet identity of 
most inhabitants of the left bank. These circumstances created favourable conditions in which an elite-led, state-building social movement could emerge on the left bank of the Dniester (Kaufman 2001, pp. 145-149).

Mass social mobilization among the inhabitants of left bank, was also expedited by the increasingly brutal rhetoric of the PFM, which became explicitly chauvinist and anti-Russian. Slogans heard at the rallies organized by the PFM included calls such as "Suitcase-station-Russia," while political platforms referred to Russian-speaking population as "occupants." In the future, they were to be deprived of civic rights or even forcibly deported. The violent attitudes of that period culminated in the fatal beating of Russian student Dima Matyushin, whose death prompted mass demonstrations of Russian-speaking population in Chişinău (Kaufman 2001, pp. 144-145; Shornikov 2003, pp. 192-201).

Social mobilization on the left bank proceeded in the name of defending Soviet values and opposing nationalism. The Councils of Workers' Collectives, formed in industrial plants, became the primary means of bringing members of the community together. The United Work Collective Council, a body coordinating their activities, was established in mid-August 1989; soon the council decided on massive strike (Babilunga 2003, pp. 150-152). The mobilization induced and steered by the local elites resulted in "psychological and actual militarization of the society" (Büsher 2010, p. 256), which proved long-lasting: its outcomes were perceptible both throughout the development of Pridnestrovian statehood and during its defence in the war of 1992.

Prior to 1990 Soviet Moldova ensured that cultural and material needs of the left-bank elites and population were satisfied. It may therefore be concluded that social and political transformations in the MSSR forged Pridnestrovie as a region-a linguistically Russified part of the Soviet Moldova on the left bank of the Dniester. However, it was not identity or regional community that was invoked in the process of social mobilization undertaken by the elite. Its underlying mainstay was attachment to Soviet values (presented as humanistic ones) and the Russian language (Kaufman 2001, pp. 145-151; Oleksy 2013, pp. 170-186).

Thus the Pridnestrovian state-building movement originated with the need to defend Soviet social realities. This conclusion is also significant insofar as it allows one to understand that whatever the left-bank elite did at the time, they did it with profound confidence in their strength. Since they defended Sovietness, a favourable response among at least some government circles in the USSR could be readily anticipated. The leadership of the Communist Party of the Soviet Union, including Mikhail Gorbachev, 
were not inclined to support the aspirations of Tiraspol, but they could count on structures associated with the force departments and the industrial sector (Kaufman 2001, pp. 152-158).

\section{THE WAR IN PRIDNESTROVIE}

The Pridnestrovian war lasted from the March 1st to July 21 1992. The question of the number of casualties is quite problematic. Immediately after the hostilities ceased, Tiraspol announced that there had been around 500 of deaths and almost 700 injured on their side. The Republic of Moldova has never made any statement concerning their official estimate. about any official calculations. The Sweden-based Uppsala Data Conflict Program provides the number of approximately 585 of deaths in the entire conflict.

Pridnestrovie started to form its own armed forces in autumn 1991, when the Republican Guard was created and the Black Sea Cossack Host was "revived." The local elite successfully effected mass mobilization of civilians, who after the outbreak of the war would also join the People's Militia and Territorial Rescue Divisions (Solak 2010, p. 103-108). Creation of the National Army of Moldova encountered many difficulties due to shortage of officers and reluctance of civilians (Shornikov 2003, p. 205-209).

The war was preceded by a number of clashes between the Moldovan police troops or sabotage groups and the Pridniestrovian armed forces. The Moldovan government was preparing to regain control over the territory of the separatist republic. On March 1st, the clash in the city of Dubossary during which an officer of the Pridnestrovian police was killed, led to escalation of conflict.

Low intensity of fighting characterized the war for a long period of time. After the initial clashes, both sides withdrew to reserve positions. Until June $19^{\text {th }}$, the war was mostly positional (except for a few minor engagements). As many soldiers and officers recollect, it would often happen that armed personnel of both sides feasted together, or commanders of two units agreed not to attack each other for 24 hours (20 let... 2012; Shornikov 2003, p. 208).

Intense and direct fighting took place in the last period of war. On June $19^{\text {th }}$, Moldova attempted to capture the city of Bendery-a right bank locality controlled by the separatists. That battle lasted until the evening of June $22^{\text {th }}$. Because of many mistakes committed by the Moldovan leadership, separatists managed to hold Bendery. It was the bloodiest period of 
that war, as most casualties, including civilians, resulted from that very battle.

The battle proved decisive for the conflict, because it caused the XIV Russian army to become officially involved in that conflict. Until that moment, the army had formally remained neutral, but the Pridnestrovian movement could rely on support given through informal channels and means. Almost $80 \%$ of the army's officers were born in Pridnestrovie, therefore their interests as well as family ties made them closely affiliated with the elite of the movement. In this light, one clearly sees what the army's commander, Gen. Gennady Yakovlev, meant when he said that he was not going to stop his officers from defending their families. Yakovlev's statement was not compatible with the official Moscow policy, so he was replaced by Gen. Yuriy Netkachev, who was doing what he could to keep the appearances of Russian neutrality (Solak 2010, p. 101). Thus the "well-disposed neutrality" of the army actually meant that its soldiers and equipment were involved in actions of the Republican Guard since the beginning of the war of 1992. At the time of the battle for Bendery general Alexander Lebed' assumed the command of the XIV army. He announced that his goal is to end that war and openly pointed to Moldova as the aggressor.

On July $6^{\text {th }}, 1992$ president of Russian Federation Boris Yeltsin and president of the Republic of Moldova Mircea Snegur signed a cease-fire agreement. On July $21^{\text {th }}$, Snegur and the Pridnestrovian leader Igor Smirnov agreed on the conditions to freeze that conflict.

The war of 1992 and the battle for Bendery is tremendously significant for the Pridnestrovian ideology and identity politics. It is definitely one of the most important or even the most important community-building myth. It has been exploited in historical politics, education, and incessantly emphasized in public life and space of the separatist republic throughout its existence. It is represented as great sacrifice of the community in the fight for its own values and land against aggressive nationalism or even rebirthed fascism - by way of association with the memory of the Great Patriotic War (Oleksy 2016, p. 259-296; Troebst 2003; Blagodatskikh 2006).

\section{DONBASS SEPARATISM IN THE 1990S AND THE REGIONAL IDENTITY OF DONBASS IN INDEPENDENT UKRAINE}

In 1991 Ukrainians, including the people of Donbass, spoke in favour of the Act of Declaration of Independence with an overwhelm- 
ing majority. Absence of decentralist tendencies in Donbass in the 1990s was due to several reasons. Firstly, as Ukraine acquired its sovereignty, the fear of potential forced ukrainization promptly expired, as no such attempts were undertaken. The Russian-speaking community of Donbass did not feel excluded from Ukrainian society (Besters-Dil'ger 2011, pp. 352-358; Kappeler 2011, pp. 11-14). Secondly, at the turn of the 1990s, the interest of the Donbass working masses began to correspond with the demands advanced by intelligentsia gathered around the People's Movement of Ukraine, and the position of the pro-republican wing of the nomenclature. The workers of the Donetsk Coal Basin were convinced that switching to independence would relieve Ukraine of the burden of "having to provide for the entire Union."

In the turbulent 1990s, milieus which opposed the striving for independence made their appearance as well. These included the Donbass International Movement, the Movement for Donbass Revival, the Democratic Donbass and Luhansk People's Movement. Their demands boiled down to upholding the Soviet Union; a new union treaty would decide whether Donbass remained in Ukraine, albeit as an autonomous entity. Otherwise the oblasts of Donetsk and Luhansk would secede and join the jurisdiction of the Russian SFSR or form a new state, although the latter was asserted only by extreme radicals (Bukkvoll 1997, pp. 28-29; Kas'yanov 2008, p. 91; Skorkin 2016). All authors discussing Donbass separatism of the early 1990s underline however, that the phenomenon was a marginal one, which was also due to lack of support from Russia. Certain authors suggest that the incentive which caused those groups to emerge came from Soviet secret services (Sizov 2015). Eventually, their potential was not activated, because for a long time Ukrainian party nomenclature maintained a conservative course, while the democratic faction came to power in Russia itself. It may be conjectured that the separatists succeeded in winning over the deeply indoctrinated members of the local intelligentsia. In 1992 an attempt was made to consolidate those milieus within the framework of the Civic Congress of Ukraine and the Labour Party. However, these groups failed to win widespread support. The Donbass International Movement initiated a local referendum which focused mainly on the prospective federal arrangement in Ukraine and furtherance of Russian as the second state language. The Donetsk and Luhansk Oblast Councils adopted resolutions on conducting the referendum as a "consulting questionnaire" together with the 1994 parliamentary elections. It produced respectively $80 \%$ and $87 \%$ support for the 
above ideas (Kuzio 2017, p. 172), but it did not entail any further action. ${ }^{1}$

The position of Donbass in Ukraine was a complicated one. This was primarily due to the difficulties in economic transformations: gigantic disparities of income and wealth, corruption and criminalization of the business environment. Given the scale of predatory privatization of the Donbass industry, the above affected the region particularly acutely. De-industrialization and subordinating mining industry to the interests of the oligarchy brought hundreds of thousands of people in Donbass on the verge of social disaster (Savitsky 2015; Kazans'kyi 2015). This was further compounded by the deterioration of material standing and loss of prestige that the mining profession enjoyed previously led to regional self-isolation.

Regional diversity of the Ukrainian state after 1991 manifested itself in electoral, geopolitical and cultural preferences (Kubicek 2000, pp. 273-274; Birch 2000; Barrington, Herron 2004). However, Donbass remained within the Ukrainian identity continuum (Wilson 2016, pp. 638-639), in which it occupied the "eastern extreme" with its opposite in Galicia (Hrytsak, Portnov, Susak 2007). The most pronounced identity traits among inhabitants of Donbass included affirmation of the Russian language and attachment to "Sovietness," as the people in the region resisted symbolic de-Sovietization.

The most serious indications of separatist tendencies were seen then in two congresses of deputies of all levels (not only from Donbass), taking place in Severodonetsk in the Luhansk oblast in 2004 and 2008. The first granted itself the right to hold a potential referendum concerning a change of the political and territorial system of Ukraine if Viktor Yushchenko assumed the office of president. Yushchenko himself, as president, almost literally left problems of Donbass outside the scope of his interest. Lack of any palpable improvement in everyday life of Ukrainians reinforced conviction that things happening in Kyiv had no impact on the situation in the Basin. After the Orange Revolution the patronage-clientelist arrangements in Donbass persisted, shielded by two "godfathers": Viktor Yanukovych, the political one (leader of the Party of Regions) and Rinat Akhmetov, the economic one (the leading oligarch of Ukraine originating from the so-called Donetsk clan). When Yanukovych became president in 2010, the media portrayed it as a takeover of Ukraine effected by the "Don-

\footnotetext{
${ }^{1}$ Nowadays, the Donbass separatists attach major importance to this event. In autumn 2014, the chairman of the People's Council of the Donetsk People's Republic, Andrei Purgin, called 1994 "the year of the birth of the Donetsk separatism" (Tret'iakova 2014).
} 
etsk people." This channelled social frustration and directed it against the inhabitants of the Basin, who were blamed for the condition of the state and associated with the authoritarian and corrupt power. Meanwhile, appropriation of authority on all levels and across Ukraine, in which "regionals" determinedly persevered, did not entail any privileges for the region from which they had come. Yet the inhabitants of the Donbass were relatively poorly involved in the Revolution of Dignity (Studenna-Skrukwa 2015, pp. 107-129).

\section{DONBASS: FROM RIOTS TO WAR}

At this point, it is crucial to make distinction between rather insignificant commitment to the Revolution of Dignity and supporting regional separatism. After Yanukovych had fled Ukraine (on February $25^{\text {th }}, 2014$ ), the atmosphere in Kyiv was one of mourning and revolutionary euphoria at the same time, but in Donbass the situation was becoming more and more dangerous. The activists of the local Euromaidans (the one in Donetsk lasted until the middle of March, the one in Luhansk almost until the end of April) were subjected to mounting pressure from the local rowdies and "activists" from beyond the eastern border. The hitherto marginal secessionist milieus were spurred into action as well. The Yanukovych-affiliated business elites who had their roots and material base in Donbass were interested in escalating the situation in the region, seeing it as an opportunity—hazardous though it may have been—to maintain or possibly heighten their position after the Euromaidan (Wilson 2016, pp. 645-646). Still, there is a hypothesis that the driving force behind the escalation of separatism in Donbass in its first phase was Rinat Akhmetov, who thus sought to achieve a stronger bargaining position with the new government of Ukraine, but the situation got out of hand utterly (see Kacewicz 2014, p. 230; Kuzio 2017, p. 188; cf. Koshkina 2015, pp. 388-390).

The first stage of rebellion began on March 1st 2014 , when the crowds, accompanied by activists of the organization Donetsk Republic proclaimed Pavel Gubarev as "people's governor." 2 Riots and unrest in Donetsk lasted throughout March, while the post-Maidan central authorities of Ukraine

\footnotetext{
${ }^{2}$ Donetsk Republic was created in 2005, representing extremist opposition against the rule of the "Orange" faction. The organization called for a division of Ukraine into six republics. Banned officially in 2007, it continued to function, though its significance was marginal. Its leader was Andrei Purgin, later one of the leading figures of DPR. See: Pravda o... 2006; Kmet' 2013.
} 
took no effective countermeasures. None of the high-ranking representative of Kyiv visited Donetsk on time. This was probably the last moment in which tragedy could have been prevented: local authorities, disgraced for having supported the regime of the "regionals" (organizing local anti-Maidans and sending groups of hired rioters called titushky to Kyiv) recognized the legitimacy of new state power immediately after Yanukovych's hasty departure. Even before the end of March, anti-war and pro-unity marches were held in Donetsk and Luhansk, both incomparably more numerous than the local Euromaidans. The new government in Kyiv attempted to save Ukrainian integrity by appointing Serhiy Taruta, oligarch and leader of the Industrial Union of Donbas, for governor. However, unlike another oligarch Ihor Kolomoyskiy, who efficiently managed the situation in the Dnipropetrovsk oblast, Taruta, who held the office of governor from March to October 2014, was not in the least successful.

The Donetsk People's Republic was proclaimed in 2014, on April 7th, while the Luhansk People's Republic on April 27th. Their "independence" was confirmed in the referendum on May $11^{\text {th }} \cdot{ }^{3}$ At the beginning of April, the "little green men" appeared on the region. On April 12th an armed group under the command of Igor Girkin (aka "Strelkov") captured Sloviansk, a small, but strategically placed town with a long history and symbolic name. This marked the beginning of the armed stage of the conflict. On April $13^{\text {th }}$, the government of Ukraine officially launched the Anti-Terrorist Operation, declaring that control over areas seized by the separatists would be soon regained. This proved impossible due to growing military involvement of Russia; its intensification was simultaneously a proof that local foundation for the militant separatism is too weak and requires to be supported from outside. ${ }^{4}$ In the first phase (April-mid-May) Russia dispatched officers of the special forces and special services, who were supposed to stir up "local insurgency." The second phase (until August) saw mercenaries and ideologically motivated fighters being deployed, Russia also supplied heavy weapons for the separatists. In the third stage (from August onwards) regular units of the Russian army entered the territory of

${ }^{3}$ According to its initiators, the turnout in the DPR was $75 \%$ with $89 \%$ votes in favour; in the LPR the turnout reached $75 \%$ as well, and $96 \%$ of votes were cast in favour. Neither referendum met the generally approved legal and democratic standards. (Donets'ki separatysty... 2014; Luhans'ki separatysty... 2014).

${ }^{4}$ Sociological surveys conducted in late March 2014 demonstrate that only $31.6 \%$ inhabitants of the Donetsk oblast were in favour of any separatist option with respect to Ukraine or questioned its statehood (incorporation of the oblast into Russia, independence of the oblast, or federation of the entire Ukraine with Russia) see: Kipen' 2014, p. 7). 
Ukraine (Mitrochin 2015). This was crucial to stop successful Ukrainian counter-offensive. On August $28^{\text {th }}-29^{\text {th }}$, Ukrainian forces suffered heavy losses near Ilovaysk ${ }^{5}$, and on September $5^{\text {th }}$ the first Minsk Protocol on cease-fire was signed. In the next stage, battles were fought for the Donbass airport and the Debaltseve bulge. On February $12^{\text {th }}, 2015$, the second Minsk Protocol was signed, but it failed to bring an end to the hostilities: the cease-fire is frequently violated and minor fighting continues to occur regularly until today (Maiorova 2017).

Today (2019) the DPR held $28 \%$ of the territory of the Donetsk oblast with $53 \%$ of its population, while the LPR had $31 \%$ of the Luhansk oblast under its control, with $68 \%$ of the population.

\section{THE IDENTITY OF PRIDNESTROVIE AFTER THE WAR}

From the standpoint of geopolitics and international relations, Pridnestrovie serves primarily to secure strategic Russian interests in the Black Sea region and in South-Eastern Europe. Thanks to a combination of political and geopolitical factors, the most important of which is financial and political support from Russia, the PMR, albeit unrecognized, has functioned for over a quarter of a century, and its continued existence seems assured, with no threats in sight. ${ }^{6}$

However, Pridnestrovie is also a social organism, inhabited currently by nearly half a million people. The fairly long persistence of Pridnestrovian (quasi)statehood, now exceeding one generation, prompted a process in which a distinct collective identity began to emerge among the inhabitants of the quasi-state. Pridnestrovie witnesses the formation of a community which may be compared to the phenomenon of state-nation (Kolstø, Malgin 1998; Guboglo 2000, pp. 14-20). Pål Kolstø observed that the Soviet period engendered "Dniester-Soviet values" in the region (Kolstø 2002, p. 7). The identity which emerged in Pridnestrovie in the early 1990s may in fact be considered a kind of "(post-)Soviet regionalism." However, when one analyzes the reasons behind the social mobilization during the conflict with the republican centre in Chişinău, one notices that they derived primarily from Soviet values. The "Dniestrian" element

${ }^{5}$ In the Donbass republics these engagements are sometimes called "our Stalingrad."

${ }^{6}$ One of the foremost of those factors is the aforementioned ability of Russia to secure their strategic interests; one should also mention the weakness of the Moldovan state and the fairly passive stance of the Western countries towards the conflict, which tends to be referred to as "Russia first policy," see: Kosienkowski 2010, pp. 219-223. 
developed as a secondary phenomenon to a range of political factors, such as the association of the left-Bank Dniester with the MSSR (would Pridnestrovian separatism have manifested itself if the region had been a part of the Ukrainian SSR?), the emancipatory, pro-Romanian and anti-Russian agenda of Chişinău and the collapse of the USSR. By and large, this made Pridnestrovian regionalism an identity of USSR orphans living on the left-bank part of the MSSR.

Studies conducted in 2016 demonstrated that $53.1 \%$ of the respondents defined themselves as "Pridnestrovians" when asked about their nationality" (Viktorov 2016). Stefan Troebst asserted that "Transnistrian people' in the sense of a demos exists. Whether this 'people' has the potential to develop into an ethnos is for the time being an open question" (Troebst 2003). Troebst wrote the above when the generation born as the USSR disintegrated or a while earlier were only in their teens. Now, a person in their twenties does not remember a different reality than the Pridnestrovian one, while a person several years their elder will associate their earliest childhood memories with the period of fighting for statehood. Throughout those years, the quasi-state has implemented a very specific and fairly consisted nation-building policy; in addition, its inhabitants have been subject to natural social processes which usually yield a collective identity.

In the recent years, the key themes of that policy have included propagating the image of Pridnestrovie as an inseparable part of Russian civilisation ("Russkiy Mir," Eurasian community) as well as inspiring and strengthening attachment to the young state. Both themes have been very closely related to regional identity. Nation-building policy in Pridnestrovie is pursued using an extensive range of instruments: from shaping the country's own historiography and academic discourse, through school education to symbolic policy. ${ }^{7}$

Local popular culture and everyday life also do influence the formation of shared identity of Pridnestrovians. The collection of unique life experiences within one state organism is very high. Observation of social life revealed a range of informal social phenomena, such as local sense of humour, colloquial language and the community of everyday life. Consequently, Pridnestrovians have become a "community of communication." ${ }^{8}$ Since the state has not been internationally recognized, many of

${ }^{7}$ An extensive analysis of nation-building policies pursued by the government of the PMR may be found in Oleksy 2016. Numerous researchers have addressed the nation-building policy of Pridnestrovian government: Blagodatskikh 2006; Troebst 2003; Kolstø 2006.

8 This was how Karl Deutsch (1953) defined contemporary nations. 
the above factors have a greater impact of its citizens than they would have in the conditions of "normal" statehood. Pridnestrovian identity did not prompt the social mobilization when the PMR was being established, but there is no doubt that it constitutes one of the outcomes of the 27 years of history of the quasi-state (Oleksy 2016, pp. 315-316).

Regionalism has played a considerable role in the formation of the Pridnestrovian community. Although it surfaced quite suddenly and did not represent the most important public sentiment, it was in fact one of the crucial factors which contributed to the creation of the PMR. Over the 27 years of the quasi-state, it has become one of the vital mainstays of local historical narration and symbolic policy.

In Pridnestrovian historiography, Pridnestrovie is a cohesive region which, in the social dimension, took its shape when these lands were a part of the Russian Empire. Pridnestrovian historians assert that very period saw the dawning of regional identity, which has to be construed as a peculiar mentality of people who had lived on "common land" for centuries rather than an attachment to a territory.

Nikolay Babilunga, the creator of Pridnestrovian historiography, underlines that the national-ethnic structure of Pridnestrovie formed in that particular period (Babilunga 2003, p. 184). What tends to be ignored is the fact that the Soviet period considerably changed that structure, not only increasing the percentage of Russian population, but also causing the arrival of people who had no previous relation to the region and practiced professions hitherto unknown there. However, Babilunga argues that at the time "favourable conditions arose in Pridnestrovie, promoting economic enterprise and facilitating peaceful labour of the representatives of numerous nationalities, who lived in peace and harmony, unconcerned with the differences of language, culture, religious beliefs, historical experience etc. (...) This is where a community was forged, one, multi-ethnic, socio-cultural community of people-Pridnestrovians, in which Slavs played the leading role" (Babilunga 2008, p. 19). Babilunga (2003, p. 182) states that the identity of Pridnestrovians "is antithetical to the militant ethnicism and linguisticism of the neighbouring republics," while the statehood of the PMR "is accepted by the population as a system of defending its land, its territory, against any attempt at dividing the people into sorts and castes."

Regionalism is also reflected in the official symbolic policy adopted by the government of the PMR. In this case, however, the attachment to land and national territory is emphasized more heavily. Such references are evident for instance in the anthem of Pridnestrovie, whose second 
stanza reads as follows: "Glorified gardens and factories/ Villages fields, cities - / For many glorious years/ work there has glorified the Fatherland. The theme recurs in the fourth stanza: We praise their native valleys/ Gray Dniester banks/ Remember about the exploits of the epic/ We thank the fathers road" (Gosudarstvennyi...). The regional aspect is also symbolized in the coat of arms of the republic, which uses the emblem of the MSSR with the added representation of the waves of the Dniester.

Another reference to "Pridnestrovian land" can be found in the Constitution of the PMR, whose preamble begins with the words "We, multinational people of the Pridnestrovskaia Moldavskaia Respublica-united by the common fortune on our land" (Constitution...). The land-related motif was also drawn upon by Igor Smirnov, one of the originators of the quasi-state and its president for two decades; one of his two books is entitled To Live on Our Land (Smirnov 2005).

Further references to Pridnestrovian landscape and territory have become one of the most popular themes in a type of contemporary cultural texts, the so-called internet memes. The beauty of the landscape is also very often mentioned on social networking sites, particularly in the group Tipichnoe Pridnestrovie on the VK.com (VKontakte) website. As a method of manifesting one's patriotism, this one belongs among the most popular. As an example, one could quote a photograph showing the broad course of the Dniester with the caption "Only an idiot does not love their country," or the \#dniestr hashtag, which accompanies photographs of the river landscapes ${ }^{9}$.

Grassroots initiatives appear to have enjoyed certain popularity in the recent years; they are aimed at geographical and historical "discovery" of the region, the republic in other words (Moe Pridnestrov'e 2017; Fech $(2014,2015,2016))$. The public found both initiatives very attractive and worthwhile; what is more, no state institution was involved in the projects in any way.

In its essence, the conflict between Tiraspol and Chişinău in 1989-1992 was not concerned with "Pridnestrovianism" but Sovietness, which people identified with Russianness (especially with respect to language). At the time, regionalism was not a driving force behind social mobilization, although it was regional distinctiveness, resulting from Soviet modernization in the previous decades, which gave the local elite an awareness of their strength and enabled them to mobilize the masses to fight for the

9 Post on social networking site Vkontakte (https://vk.com/pmr.online? $z=$ photo-42339 067_456241033\%2Falbum-42339067_00\%2Frev [accessed 14.02.2017]). 
privileges they had once acquired. The 27 year period in which the quasi-state continued to function, yielded a new identity, grounded mainly in the attachment to the young and unrecognized republic, as well as in the sense of a bond with "Russian civilization." It may therefore be concluded that unconscious regionalism provided a foundation on which to build the quasi-state, while once it had been "discovered" by the local elites, it became an underpinning of the nation-building ideology.

\section{THE DONBASS “HYBRID REPUBLIC” IDENTITY AS AN AFTERMATH OF THE WAR}

The ideological and political formula of the DPR and the LPR represents an amalgam of several ideological projects, warlordism and external instruments. On the symbolic plane, the DPR draws on the Donetsk-Krivoy Rog Republic (DKR), short-lived Bolshevik state of 1918. The black-blue-red flag used initially by the Donetsk Republic organization and then by the DPR is claimed to have been the historic flag of the DKR from $1918 .{ }^{10}$ At the same time, the symbolism of the flag is asserted to denote Orthodox religion (Deputaty... 2014). The emblem of the DPR is a synthesis of Russian imperial symbols (two-headed but legless eagle), surprising elements of Ukrainian symbolism, most likely construed as Little Russian (Archangel Michael) and doubtful_-given their historical accuracy—written references to historic Rus'.

The LPR is a "clone" of the DPR and does not have its own historical traditions. The flag of the republic is composed of light blue, blue and red horizontal stripes. Three successive variants of the coat of arms appeared. The first was used from spring to November 2014, and combined the Russian two-headed eagle with the coat of arms of the city of Luhansk (furnaces). The second, used briefly in November 2014, was a modified coat of arms of the Luhansk oblast in independent Ukraine, where the blue and yellow ribbon was replaced with an orange-black Ribbon of Saint George, associated with Russian military. Finally, the coat of arms in use since November 2014 is unambiguously Soviet in its aesthetic and symbolic aspects, representing a red, five-pointed star surrounded with a wreath of ears of grain.

Among those fighting on the side of the DPR and LPR there were volunteers from outside the region, whose ideological backgrounds var-

${ }^{10}$ In reality, being a revolutionary creation of the Bolsheviks, the DKR used solely red flags. 
ied greatly: Russian Pan-Slavists, neo-imperialists and neo-communists, Cossacks, Orthodox fundamentalists, extreme right-wingers from Western Europe and Serbian Chetniks looking for a revenge on the West for the loss of Kosovo. If one were to look for a common ideological denominator for the DPR and LPR, pro-Russian agenda and anti-Occidentalism would be the most likely answer. All political groups on the political scene of the DPR and LPR refer implicitly or explicitly to the "Russkiy Mir," a concept of cross-border community brought together by the Russian language, shared historical memory, commonality of civilizational background and "unique" lifestyle (Kardaś et al. 2014; Kościński 2015).

People's power or rule of the people is an important notion in the official discourse in the Donetsk and Luhansk republics, reflected in their very names. People's power is constructed in opposition to Western party-based democracy. The factions in the legislative bodies of the DPR and LPR are called social movements instead of parties, they do not have platforms or programmes but "projects." At the same time, social motivations can be detected here. Until 2014, the originators of the DPR and LPR functioned on the fringe of political life (if they participated in it at all) and occupied inferior positions in social hierarchy. None of the significant leaders of the DPR and LPR, except perhaps for the "head" (2014-2018) of the DPR, Aleksandr Zakharchenko, had any direct connection to mining industry, which was one of the key elements of regional identity. What is more, reportage-based accounts demonstrate clearly that the "people's power" relies on terror, while the number of refugees from Donbass exceeds 1,6 million people (Szymanik and Wizowska 2016; Kwiatkowska-Moskalewicz 2016; Report on... 2017). In conclusion, the separatist drive of a part of Donbass, which materialized in spring 2014, is a contrivance of only some of its inhabitants, collaborating with external power interested in long-term destabilization of Ukraine.

The efforts to legitimize the statehood of both self-proclaimed republics also include a historical policy, which is unequivocally based on war as the main source of identity. The axis of the new Donbass "national history" relies on the parallel established between the interpretation of events in the war of 1941-1945 (compatible with Soviet historiography), and the interpretation of the present conflict which essentially consists in fighting fascism, as in the case of World War II. The pantheon of Donbass national heroes is kept up to date: veterans of the Great Patriotic War are joined by the republican leaders who are killed as the fighting continues. The composition of the new pantheon, however, is quite evidently linked to the internal struggle for power. Attempts are made to estab- 
lish "national" holidays commemorating the victory over the Ukrainian side. In both republics, new doctrines of historical education have been introduced, where Donbass is dissociated from Ukraine and integrated into a narrative about Russian history. Furthermore, in order to stimulate local patriotism, specific educational modules have been introduced. In the DPR, those are the so-called "citizenship lessons": "Donbass-my homeland," "Grow up as a citizen of the Donetsk People's Republic," or "Donbass and the Russian world." In the LPR, there is the off-school "Spiritual and moral education program for pupils and students of the Lugansk People's Republic" and "Basics of Orthodox culture " (Abibok 2018).

A prominent example of popular identity-building through reference to the recent war can be seen in the trailer of LPR's war-themed blockbuster (promoted as a "people's feature film"): the film Opolchenochka, a film about Svetlana Dryuk, female deputy commander of a tank regiment in the DPR/LPR forces is scheduled to premiere on May $9^{\text {th }}, 2019$, a date which is by no means coincidental (Legendarnaya... 2019). ${ }^{11}$

\section{CONCLUSIONS}

Regionalism and regional identity appear to be a fairly straightforward explanation when one seeks to account for separatist tendencies in Eastern Europe. However, an in-depth analysis of the case histories of Donbass and Pridnestrovie demonstrates that the identity may play a substantial role in social and political processes, and it may be constructed through war, but its becoming a foundation for separatism hinges upon the interests of the local elites and external, cultural and political factors.

The left-bank elites of the Soviet Moldova embarked on a process of separation and state-building mass mobilization, which led the region to armed conflict with the home state. While the main purpose of the elite was to defend their social and political privileges, the main mobilization tools were tied with the strong Soviet identity of the masses. Pridnestrovie, emerged as a quasi-state in the wake of that process and the armed conflict in 1992. Subsequently, to create a long-lasting identity in post-Soviet Europe, the local elite had to appeal to other values: Russian culture and regionalism. The memory of the victorious war and the tremendous sacrifice made to defend "own values and land" are some of the key elements of the Pridnestrovian state ideology and identity. That myth is strongly connected with the newly shaped regional identity, and the two

\footnotetext{
11 The heroine of movie defected to the Ukrainian side in March 2019.
} 
phenomena are complementary. Also, Prindestrovie remains strongly militarised in the field of public culture while the armed forces (local army and Russian peacekeepers) are-quite deliberately-well visible. Nevertheless, the 1992 ceasefire is effective and the risk of resumption of military action is low. After all, the political elite of Pridniestrovie has always been thoroughly civilian, originating from the Soviet nomenclature or the new business class (post-Soviet oligarchs with a criminal past).

At the moment of the collapse of the USSR, the regional identity of Donbass had been established and had relatively deep historical roots. The local elite did not have to start a war in the name of identity, because Ukraine's independence did not pose a threat to the position of these elites; on the contrary, it created an opportunity to expand their influence on the entire state. The separatist milieus remained marginal. In independent Ukraine, Donbass stood for authoritarianism, corruption, criminalization as well as pro-Russian geopolitical and cultural leanings, but it was not associated with separatist tendencies pursued by armed force. The rebellion and the subsequent war in Donbass broke out at the time of a deep crisis of the Ukrainian state, used by Russia for its geopolitical and revanchist goals. There is a hypothesis that the then oligarchic elite of Ukraine originating from the Donbass region origin tried to exploit the separatist scenario for its own purposes. Even if that was the case, they lost control of the situation. The leadership of the rebellion and war was taken over by the local marginal extremists and the warmongers of the hybrid war sent from Russia.

In contrast to the relatively "non-aggressive" war in Moldova, the aggressiveness and harshness of separatists and Russians in Donbass towards Ukrainian combatants were very high. One of the possible reasons was that the war was approached as a punitive action against Ukraine for its "betrayal of the Russkiy Mir" (Kuzio 2017, p. 270). Nothing of the king happened in Pridnestrovie, because the issues of the right-bank Moldova were problems of secondary importance for the left-bank combatants. Moreover, in both conflicts the questions of territory were altogether different: for Pridnestrovie, the war of 1992 was a defensive conflict, because the republic had already been determined in terms of territory. Meanwhile, the separatists from Donbass tried to seize as much land of the historical region as it was possible (with an ambition to have the separatist tendency spread into the south Ukraine as well).

In Donbass, a new eclectic regional identity is still being built in the chaos of war and warlordism. To a large extent, it is a patchwork of the locally invented tradition (references to the DKR), cultivated earlier by mar- 
ginal milieus and the localized variant of the Russian concept of "Russkiy Mir." The war brought new elites to power-the leadership of the LPR and the DPR have originated entirely from the ranks of the fighting separatists. At the same time, the frequent sudden deaths of the LPR and DPR leaders indicate that either these people are strongly conflicted with one other and settle warlord-like scores, or they are only a tool in the hands of external forces. The identity built in the DPR and the LPR is undoubtedly constructed through war. However, given that a significant part of the population have relocated and there is a terror policy directed against those who think differently than the separatist leadership, it is very doubtful whether this identity can be called a regional one; or rather imposed on the region.

The analysis of the cases of Donbass and Pridnestrovie contributes much to the deliberations concerning regional identity, separatism and its potential to fuel armed conflict. These examples demonstrate that regional identity does not have to be grounded in centuries-long tradition or unique geographic circumstances. Relatively recent modernization and industrialization processes can provide sufficient foundation for such an identity, ${ }^{12}$ while in the political dimension, it can be precipitated by intense social and political transformation, as in the case of Pridnestrovie. On the other hand, the interests of the regional elite can lead to its political suppression, as in the case of Donbass. As regards the latter, the emergence of the separatist drive and the war in 2014 should be viewed in the light of the imperial designs of Russia and the weakness of the Ukrainian state, not as an embodiment of the revival of Donbass regional identity.

\section{REFERENCES}

Abibok, Julia. 2018. “Na drodze do stworzenia 'narodu Donbasu'. Polityka tożsamości samozwańczych republik na wschodzie Ukrainy." Komentarze OSW 270, June 5.

Assmann, Jan. 1992. Das kulturelle Gedächtnis: Schrift, Erinnerung und politische Identität in frühen Hochkulturen. Munich: Verlag C.H. Beck.

Babilunga, Nikolai. 2003. "Pridnestrov'skii konflikt: istoki, harakter, osobennosti." In: Nikolai Babilunga (ed.). Fenomen Pridnestrov'ia. Tiraspol: RIO PGU.

Babilunga, Nikolai. 2008. "Istoriia Pridnestrov'ya. Kratkii ocherk.” In: Kimitaka Macuzato (ed.). Pridnestrov'e v makroregional'nom kontekste chernomorskogo poberezh' ya. Sapporo: Slavic Research Center, Hokkaido University.

Babilunga, Nikolai. 2015. Pridnestrov'e: shagi istorii. Tiraspol: MID PMR.

${ }^{12}$ A similar view on the issue is expressed by authors of the study edited by Melanie Tatur (2004). 
Banasik, Mirosław. 2015. "How to understand the hybrid war." Securitologia 1.

Barrington, Lowell W., Erik S. Herron. 2004. "One Ukraine or many? Regionalism in Ukraine and its political consequences." Nationalities Papers 32, 1.

Besters-Dil'ger, Yuliya [= Besters-Dilger Juliane]. 2011. "Natsiya ta mova pislya 1991 roku — ukrayins'ka ta rosiis'ka v movnomu konflikti.” In: Andreas Kappeler (ed.). Ukrayina. Procesy natsiotvorennya. Kyyiv: K.I.S.

Birch, Sarah. 2000. "Interpreting the Regional Effect in Ukrainian Politics." Europe-Asia Studies 52,6 .

Blagodatskikh, Iirina. 2006. "Ideological resource of Pridnestrovian statehood." In: Beril S. Galinskii, Iirina Blagodatskikh (eds). The International Law and Modern World Realities: The Pridniestrovian Moldovan Republic as Full-fledged State. Tiraspol: RIO PGU.

Bukkvoll, Tor. 1997. Ukraine and European Security. London: Bloomsbury USA Academic.

Büsher, Klemens. 2010. “Gosudarstvennost' Pridnestrov'ya — avari'ya v hode istorii?” In: Egbert Jahn (ed.). Natsionalizm v pozdne-i postkommunisticheskoi Evrope. Tom 3: Natsionalizm $v$ natsional'no-territorial'nyh obrazovaniah. Moskva: Rosspen.

Deutsch, Karl. 1953. Nationalism and Social Communication: An Inquiry into the Foundations of Nationality. Cambridge: M.I.T Press.

Fech, Nikolai. 2014. "Rashkovo. Istoriia liubvi." Pridnestrov'e 11, August 9.

Fech Nikolai. 2015. "Krest Iagellonov: perezagruzka." Pridnestrov'e 8, February 28.

Fech Nikolai. 2016. "Posledniaya tsitadel." Pridnestrov'e 3, November 18.

Galushchenko, Oleg. 2001. Naselenie Moldavskoi ASSR (1924-1940 gg.). Chişinău: Akademiia Nauk Respubliki Moldova.

Guboglo, Mikhail. 2000. "Tiazhkoe bremiya konkuriruyushchikh identichnostei. Opyt Pridnestrov'ia." Istroricheskii almanakh Pridnestrov'ya 4.

Hrytsak, Yaroslav, Andrii Portnov, Viktor Susak (eds). 2007. Ukrayina moderna. Spetsyal'nyi vypusk: L'viv-Donets'k: sotsiyal'ni identychnosti v suchasnii Ukrayini. Kyyiv: Krytyka.

Kabuzan, Vladimir M. 1976. Zaselenie Novorossii (Ekaterinoslavskoi i Khersonskoi gubernii) v XVIII - pervoi polovine XIX veka (1719-1858). Moskva: Nauka.

Kacewicz, Michał. 2014. Sotnie wolności. Ukraina od Majdanu do Donbasu. Warszawa: Axel Springer Polska.

Kaldor, Mary. 2013. "In Defence of New Wars". Stability: International Journal of Security and Development, 2(1), Art. 4 (DOI: 10.5334/sta.at).

Kappeler, Andreas. 2011. "Hromadyans'ka chy etnichna natsiya? Zauvahy z teoriyi ta istoriohrafiyi." In: Andreas Kappeler (ed.). Ukrayina. Procesy natsiotvorennya. Kyyiv: K.I.S.

Kardaś, Szymon, Sławomir Popowski, Aleksiej Wasiliew, Marta Studenna-Skrukwa. 2014. "Russkij Mir: wspólnota wyobrażona czy rosyjskie soft power?", Grzegorz Skrukwa (ed.). In: Marta Studenna-Skrukwa, Anna Stryjakowska (eds.). Rosja w XXI wieku. Zagrożenia. Wyzwania. Perspektywy. Poznań, e-wydawnictwo (http://www.e-wydawnictwo.eu/ Document/DocumentPreview/4353).

Kas'yanov, Heorhii. 2008. Ukrayina 1991-2007. Narysy novitn'oyi istoriyi. Kyyiv: Nash Chas.

Kaufman, Stuart J. 2001. Modern Hatreds: The Symbolic Politics of Ethnic Wars. Ithaca: Cornell University Press.

Kazans'kyi, Denis. 2015. Chorna lykhomanka: nelehal;nyi vydobutok vuhillya na Donbasi. Kyyiv: Tempora. 
Kipen', Volodymyr. 2014. “'Travmovana svidomist' yak naslidok i faktor nestabil'nosti (doslidzhennya masovykh nastroiv zhyteliv Donec'ka”. Skhid 2, 128 (http://skhid.com. ua/article/view/24557/22158 [accessed 24.10.2017]).

Kmet', Stanislav. 2013. "Militsiya i russkii fashizm v Donetske. Kto komu sluzhyt?" Ostrov, April 10 (http://www.ostro.org/general/politics/articles/417825 [accessed 24. 10.2017]).

Kolstø, Pål. 2002. "Introduction.” In: Pål Kolstø (ed.). National Integration and Violent Conflict in Post-Soviet Societies. The Case of Estonia and Moldova. Lanham, MD: Rowman \& Littlefield.

Kolstø, Pål. 2006. "The Sustainability and Future of Unrecognized Quasi-States.” Journal of Peace Research 6.

Kolstø, Pål, Andrei Malgin. 1998. “The Transnistrian Republic: a Case of Politicized Regionalism." Nationalities Papers 1.

Kononov, Illya F. 2000. Etnos. Tsinnosti. Komunikatsiya. Donbas v etnokul'turnykh koordynatakh Ukrayiny. Luhansk: Al'ma Mater.

Kononov, Illya F. 2006. "Donbas ta Halychyna: prychyny napruzhenosti v stosunkakh ta poshuk istorychnoho kompromisu." In: Illya F. Kononov (ed.). Stosunky Skhodu ta Zakhodu Ukrayiny: mynule, s'ohodennya ta maibutne. Luhansk: Znannya.

Kornilov, Vladimir. 2011. Donetsko-Krivorozhskaya respublika. Rasstrelyannaya mechta. Kharkiv: Folio.

Koshkina, Sonya. 2015. Maidan. Nerozkazana istoriya. Kyyiv: Brait Star Pablishynh.

Kosienkowski, Marcin. 2010. Naddniestrzańska Republika Mołdawska. Determinanty przetrwania. Toruń: Wydawnictwo Adam Marszałek.

Kościński, Piotr. 2015. “'Russkij mir’ — rosyjska polityka sąsiedztwa”, Sprawy Międzynarodowe, 1.

Kramar, Oleksandr. 2014. “'Spetszona' Ukrainy. Shcho my vtrachayemo na Donbasi.” Tyzhden'.ua, September 12 (http://tyzhden.ua/Politics/118905 [accessed 19.02.2017]).

Kubicek, Paul. 2000. "Regional Polarisation in Ukraine: Public Opinion, Voting and Legislative Behaviour." Europe-Asia Studies 52, 2.

Kuzio, Taras. 2007. Ukraine - Crimea - Russia. Triangle of Conflict. Stuttgart: Ibidem-Verlag.

Kuzio, Taras. 2017. Putin's War Against Ukraine. Revolution, Nationalism and Crime. CreateSpace Independent Publishing Platform, Chair of Ukrainian Studies University of Toronto: Toronto.

Kwiatkowska-Moskalewicz, Katarzyna. 2016. Zabićsmoka. Ukraińskie rewolucje. Wołowiec: Wydawnictwo Czarne.

Lindner, Rainer. 2008. Pidpryyemtsi i misto v Ukrayini, 1860-1914. Industrializatsiya $i$ sotsial'na komunikatsiya na Pivdni Rosiis'koyi imperiyi. Donetsk: Promin'.

Maiorova, Alina (ed.). 2017. Donbas in Flames. Guide to the Conflict Zone. Lviv: Prometheus.

Malendowski, Włodzimierz. 2003. "Nowa jakość konfliktów zbrojnych na przełomie XX i XXI wieku. Przyczyny - uwarunkowania - skutki.” In: Włodzimierz Malendowski (ed.). Zbrojne konflikty i spory międzynarodowe u progu XXI wieku. Analiza problemów $i$ studia przypadków. Wrocław: Atla2.

Martyn, Teri [= Martin Terry]. 2013. Imperiya natsional'noho vyrivnyuvannya. Natsiyi ta natsionalizm u Radyans'komu Soyuzi (1923-1939 roky). Kyyiv: Krytyka.

Mitrochin, Nikolay. 2015. "Infiltration, Instruction, Invasion: Russia's War in the Donbass." Journal of Soviet and Post-Soviet Politics and Society, 1. 
Oleksy, Piotr. 2013. "Mołdawski nacjonalizm vs. naddniestrzańska państwowotwórczość. Przesłanki społecznej mobilizacji w konflikcie naddniestrzańskim." Sensus Historiae 11.

Oleksy, Piotr. 2016. Wspólnota z przypadku. Studium tożsamości mieszkańców Naddniestrza. Gniezno: Instytut Kultury Europejskiej UAM.

Reginia-Zacharski, Jacek. 2014. Wojna $w$ świecie współczesnym: uczestnicy, cele, modele, teorie. Łódź: Wydawnictwo Uniwersytetu Łódzkiego.

Savitsky, Oleg. 2015. Towards the End of the Coal Age in Ukraine?! A Review of the Ukrainian Coal Sector in the Context of the Donbass Crisis. Kyiv: Heinrich Böll Foundation (https:// ua.boell.org/sites/default/files/a5_web_layout_kiev_boell.pdf).

Shornikov, Petr. 2003. "Pridnestrov'e v kontekste grazhdanskogo konflikta v Moldavii: vzgliad iz Kishineva.” In: Nikolai Babilunga (ed.). Fenomen Pridnestrov'ia. Tiraspol: RIO PGU.

Sizov, Vitalii. 2015. “Kgbshnye korni 'DNR'.” Donetskaya Pravda, August 13 (http://pravda. dn.ua/article/337-kgbshnye-korny-DNR [accessed 19.02.2017]).

Skorkin, Konstantin. 2016. "25 let donbasskogo separatizma." Real'naya gazeta, 15 March (http://realgazeta.com.ua/25-let-donbasskogo-separatizma-1 [accessed 19.02.2017]).

Smirnov, Igor. 2005. Zhit' na nashei zemle. Moskva: Sovietskiy pisatel'.

Solak, Jan. 2010. Mołdowa. Republika na trzy pęknięta. Historyczno-społeczny, militarny i geopolityczny wymiar "zamrożonego konfliktu" o Naddniestrze. Toruń: Wydawnictwo Adam Marszałek.

Straub, Jürgen. 2006. “Tożsamość osobista i zbiorowa. Analiza pojęciowa”. In: Aleksandra Jasińska, Lech A. Nijakowski, Jerzy Szacki, Marek Ziółkowski (eds.). Wspótczesne teorie socjologiczne. Warszawa: Scholar.

Studenna-Skrukwa, Marta. 2014. Ukraiński Donbas. Oblicza tożsamości regionalnej. Poznań: Wydawnictwo Nauka i Informacje.

Studenna-Skrukwa, Marta. 2015. "Rewolucja, której nie było? Euromajdan w stolicy Donbasu." In: Grzegorz Skrukwa, Marta Studenna-Skrukwa (eds.). Rewolucja w imię godności. Ukraiński Euromajdan 2013-2014. Toruń: Wydawnictwo Adam Marszałek.

Szymanik, Grzegorz, Julia Wizowska. 2016. Po pótnocy w Doniecku. Warszawa: Wydawnictwo Agora.

Tatur, Melanie. 2004. "Introduction: Conceptualising the Analysis of 'Making Regions' in Post-socialist Europe." In: Melanie Tatur (ed.). The Making of Regions in Post-Socialist Europe - the Impact of Culture, Economic Structure and Institutions. Case studies from Poland, Hungary, Romania and Ukraine. Wiesbaden: VS Verlag für Sozialwissenschaften.

Tret'iakova, Marina. 2014. "Referendum o federalizatsii Donbassa: 20 let bor'by." Aktual'nye kommentarii, November 9 (http://actualcomment.ru/referendum-o-federalizatsii-donba ssa-20-let-borby.html [accessed 22.03.2019]).

Troebst, Stephane. 2002/2003. "Transdniestrian Moldovan Republic: From Conflict-Driven State-Building to State-Driven Nation-Building." European Yearbook of Minority Issues.

Troebst, Stephane. 2003. “'We are Transnistrians!' The Post-Soviet Identity Management in Dniestr Valley." Ab Imperio 1.

Viktorov, Igor. 2016. "My - Pridnestrov'tsy". Pridnestrov'e, May 17 (http://pridnestroviedaily.net/archives/11381 [accessed 13.02.2017]).

Wilson, Andrew. 2016. "The Donbas in 2014: Explaining Civil Conflict Perhaps, but not Civil War.” Europe-Asia Studies 68, 4. 
"20 let konflikta w Pridnestrov'e: Dnem voevali a vecherom vmeste vino pili." 2012. Segodnya.ua, June 19 (http://www.segodnya.ua/world/20-let-konfliktu-v-pridnectrovednem-voevali-a-vecherom-vmecte-pili-vino.html [accessed 02.02.2017]).

"Constitution of the Pridnestrovskaya Moldavskaya Respublica." Ministry of Foreign Affairs of the Pridnestrovian Moldovan Republic (http://mfa-pmr.org/en/constitution [accessed 13.02.2017]).

"Deputaty DPR utverdili gerb i flag respubliki." 2014. TASS, June 21 (http://tass.ru/mezhdu narodnaya-panorama/1271627 [accessed 19.02.2017]).

“Donets'ki separatysty vyyavylysya sprytnymy pidrakhuyamy." 2014. Ukrains'ka Pravda, May 11 (http://www.pravda.com.ua/news/2014/05/11/7025032 [accessed 19.02. 2017]).

“Gosudarstvennyi gimn.” Pridnestrov'skaya Moldavskaya Respublika. Oficial'nyı̆ saŭt pravitel'stva (http://gov-pmr.org/symbols [accessed 13.02.2017]).

"Legendarnaya tankistka iz LNR, geroinya fil'ma 'Opolchenochka' pereshla na storonu Ukrainy.” 2019. Primechanya, March 4 (https://primechaniya.ru/home/news/mart-2019 /legendarnaya-tankistka-iz-dnr-geroinya-filma-opolchenochka-pereshla-na-storonu-ukr ainy [accessed 21.03.2019]).

"Luhans'ki separatysty oholosyly ostatochni rezul'taty "referendumu"'. 2014. Ukrains'ka Pravda, May 12 (http://www.pravda.com.ua/news/2014/05/12/7025091 [accessed 19. 02.2017]).

“Moe Pridnestrov'e." 2017. Aleksandr Palamar website (https://www.palamar-photo.com [accessed 14.02.2019]).

"Pravda o donetskikh separatistakh." 2006. Evraziya, September 15 (http://www.evrazia.org $/$ modules.php? name $=$ News \&file $=$ article $\&$ sid $=3264$ [accessed 19.02.2017]).

Report on the human rights situation in Ukraine 16 November 2016 to 15 February 2017. Office of the United Nations High Commissioner for Human Rights (http://www.ohchr.org/Documents/Countries/UA/UAReport17th_EN.pdf [accessed 14.04.2017]).

"V Pridnestrov'e prozhivaiyut 475007 chelovek." 2017. Vesti PMR, February 27 (http:// vestipmr.info/articles/2017/02/27/v-pridnestrove-prozhivayut-475-007-chelovek [accessed 06.05.2018]).

\section{REGIONAL IDENTITY, SEPARATISM, AND WAR IN EASTERN EUROPE: DONBASS AND PRIDNESTROVIE}

Piotr Oleksy, Marta Studenna-Skrukwa

(Adam Mickiewicz University, Poznań)

\section{Abstract}

The authors of this article use the examples of the Donbass and Pridnestrovie regions to examine the relationship between regional identity, separatism, and armed conflict. On the basis of comparative methods of analysis, they describe the historical and sociological processes and political conditions that, over the 
course of history, produced the formation of a specific sense of regional separateness among the inhabitants of those regions. They prove that regional identity need not rest on centuries of tradition and that Soviet modernization could be a key component of that identity. This analysis of the relation between regional identity and war indicates that the popular explanation of the underpinnings of separatism in Eastern Europe by reference to identity is insufficient in the case of these two regions. In contemporary Donbass and in Pridnestrovie both, identity is constructed on the basis of a war narrative but has become a foundation for effective separatism only in connection with the interests of the local elites and/or external political and cultural factors.

\section{Key words / słowa kluczowe}

Donbass / Donbas, Pridnestrovie / Naddniestrze, regional identity / tożsamość regionalna, regional elites / elity regionalne, separatism / separatyzm, war / wojna 